\title{
With the IAU and inside the IAU since 1946
}

\section{Jean-Claude Pecker}

\author{
Collège de France, Paris \\ Past General Secretary (1964-1967) \\ email: j.c.pecker@wanadoo.fr
}

\begin{abstract}
In this presentation the author narrates some key episodes of his life of serving the IAU for more than seventy years.

Astronomy, more than most sciences, requires an international collaboration. It is the duty of the IAU to insure, between astronomers of the whole world, scientific and human relations. Less than 1,000 astronomers at the time (1946) of my first papers, more than 10,000 today: this means many international collaborations, and many faithful friendships, through several General Assemblies, and many Symposia and Colloquia. To the young astronomers, I must only wish : Cheer up !

Not being able to participate to the XXXth General Assembly in Vienna, the author sent a video presentation (available on the Vienna GA web site), and also provided a spoken text (in French) that was rendered in written form by a voice-to-text software. This text, a recollection of the author's life "inside the IAU", was then translated and formatted by Chris Sterken. The English version follows; the original French text is included as an Appendix.
\end{abstract}

Keywords. IAU Commission 13, IAU Commission 38, Carte du Ciel

Since very early on I had a truly close relationship with the International Astronomical Union (IAU). In 1946, I started my graduate student life. I wished to orient myself towards stellar atmospheres, a field that in those days was little developed in France. My mentor, Evry Schatzman (who became my lifelong friend), had told me very clearly that, being a specialist in stellar interiors, he would not be able to supervise my research, and that I had thus to go abroad to learn my profession. It was, according to him, to Utrecht that I should go. But in those days, the control on currency exchange was very tight, and one could not easily travel abroad, and, in the Netherlands, one could not be paid in French francs; finding accommodation also was nearly impossible. It is thanks to the IAU that these problems could be solved. At the time, Lieutenant-Colonel Stratton who had been IAU General Secretary - was President of the Commission he had set up, viz. Commission 38 "Échanges d'astronomes" (Past Commission 38, Exchange of Astronomers).

Thus, an exchange came about between Jakob Houtgast, who wished to work in France, and myself: we swapped salary and apartments. I shared his apartment with Kees de Jager, who was also working on his thesis. This was, under the aegis of the IAU, a pleasant and fruitful stay, directed by wonderful Marcel Minnaert, who has remained for me till today the tutelar image of a benevolent mentor. The year was productive: we wrote many papers on the formation of solar and stellar spectral lines. This exchange, under the aegis of Commission 38, could be extended to the next year until 1948; and similarly, when Mogens Rudkjöbing spent a year at the Institut d'Astrophysique de Paris (IAP), I spent several months in Copenhagen, where I learned from Bengt Strömgren the construction of "non-gray" stellar-atmosphere models... Another marvelous year: thanks to IAU Commission 38! 
In 1948, the General Assembly (GA) in Zürich was the first opportunity, after the war, for astronomers of the entire world to get together, like they had done in 1938 in Stockholm. Of course, I was too young to participate. But I remember that already in 1947, we had been visited in Utrecht by Édith Müller, who was preparing the organisation of this GA, and who brought Swiss chocolates for the young researchers in Utrecht. Splendid Edith!

In 1951 the IAU GA was to take place in Leningrad. But the political atmosphere was that of the cold war; the majority of the Executive Committee (EC; mainly its President Bertil Lindblad and his General Secretary Bengt Strömgren) decided to cancel the GA. A certain number of astronomers protested, among whom of course Minnaert, Schatzman, de Jager and myself. Our Italian colleagues offered to hold the GA in Rome; but for evident organisational reasons, we had to wait until 1952. The 1952 GA was for me the opening to the great world of global astronomy.

In January and February 1952 I had participated in the Bureau des Longitudes expedition to Khartoum (then in Anglo-Egyptian Sudan) for observing the solar eclipse of February 25. Our team, with Marius Laffineur who led it, Raymond Michard and André Cassagnol, obtained very good results that I was asked to present to Commission 13 (Éclipses solaires) presided over by Donald Menzel, the director of Harvard Observatory. Apparently, he liked my presentation. He provided me with a superb tie, and above all he proposed a Fulbright grant to spend a year at the High Altitude Observatory (HAO) in Boulder (Colorado) with his director Walker Orr Roberts. That stay was exciting. Merci, IAU Commission 13!

After Rome 1952, came Dublin 1955... I went there, as well as to all the later IAU GAs - except, alas, the last two: Honolulu and Vienna. The following GA, in 1958, finally took place in the USSR, in Moscow. It was for many reasons a memorable meeting. Schatzman and I were somehow shocked by the fact that certain new Commissions (Commission 40, radio astronomy, especially), but also older Commissions (Carte du $\mathrm{Ciel}$, for example), were technical Commissions whose interests were spread out over various scientific Commissions... Where would one henceforth speak about the solar corona? Commission 40, or Commission 13, indeed 12 or 10...?

It appeared to us that a reorganisation of the Commissions, with perhaps a system with double access, would be needed, and we sent a letter to the Executive Committee, which, as I remember it now with pleasure, we had written in a rather incendiary tone. We had reacted, and we were happy with ourselves - and of course we didn't give it any further thoughts...

Time passes. In the course of the following year, Schatzman and I received a phone call from Donald Sadler, the General Secretary, who had accepted a second mandate of three years, to invite us for a meeting with IAU President Jan Oort and Piet Oosterhoff, who assumed the (non statutory!) role of Assistant General Secretary. These were very busy days in Leiden: the best restaurants in town, the city's most beautiful museums, ... But also some debates with our hosts. The outcome was not a big deal, and we returned happily to Paris.

The summer of 1961 was that of the GA in Berkeley. As soon as I had arrived on campus, I found in my pidgeon hole[sic]† a note from Donald Sadler: "I need to see you as soon as you arrive". I rushed to his office:

"The EC has decided to create the new function of Assistant General Secretary; do you want to become Assistant General Secretary of the IAU during the next three years?"

$\dagger$ Note from the Editors: This is the name for a letter box that was previded to each participant. 
Great surprise on my side. It was a great honour, in a way the recognition of the status of an astronomer of international reputation, and the conclusion of our meetings in Leiden.

\section{"I am very honoured, but I still have to think it over."}

"Certainly! I want your reply before the forthcoming meeting of the EC, next Saturday".

I thus consulted my mentors, first André Danjon, the "pope" of French astronomy, Director of the Paris Observatory and member of the IAU EC: "You must accept it - for France". My mentor, Évry Schatzman: "Of course you must accept ... that will permit me to become president ...(!!)". My old master, Marcel Minnaert: "You must accept; it is an opportunity for our progressive ideas". One single voice was discordant, that of Jean-François Denisse, the master of French radio astronomy: "You must refuse. If you accept, your scientific career is ruined..." I followed my ambition and I accepted. I have never regretted it.

The three following years, 1961-1964, at the side of Donald Sadler, were years of learning. The relations with IAU President Victor Ambartsumian were rare but excellent; he had asked us not to flood him with useless postal mail. I was in charge of the IAU publications, of organising symposia and of editing their Proceedings. With my secretary, dear Geneviève Drouin, we made frequent trips to Birkenhead (near Liverpool), where our printer resided, an intrepid man whose name I forgot, but who did an excellent job for the publication of the Transactions. I also had to travel frequently to Herstmonceux, where the Royal Greenwich Observatory had been relocated. I was housed in the castle, and could share my breakfasts with the Astronomer Royal, Sir Richard Woolley; it even happened to me to hold a cricket bat... but mostly I worked with Sadler. Donald and I had decided to publish a third volume of the Transactions: the Astronomer's Handbook, published in our two languages, head to tail. It was the only one in the history of the IAU, and I regret that. It is also during this period that the homogenisation of symbols, initials and abbreviations, for the use by all editors in their publications, was introduced.

Then came the GA in Hamburg, in August 1964. I was to become General Secretary. My first contact with Germany since the war, a contact in halftones; I had suffered a lot in 1944... The President of the Organising Committee was Otto Heckmann, a calm man, wise and effective. It was a good GA. The new IAU President was Pol Swings, director of the Institut d'Astrophysique de Liège, whom I had already known for many years because of my frequent attendance to the excellent Liège annual colloquia. Working with my friend Pol was extremely easy, since I could travel by car from Paris to Liège, and even from Nice (I was Director of the Observatory at the time), without any difficulties. The Assistant General Secretary was Luboš Perek, a particuliarly wise choice, since he could more easily solve the problems related to the organisation of the next GA in Prague, planned for 1967. I quickly found a true friend in this excellent successor... We often had a rendezvous in improbable places, in the morning hours: in front of the Taj Mahal at 6 a.m., or on the Pont des Arts in Paris, at sunrise... The essential problem of this triennium was the organisation of the Prague GA. It is clear that Luboš was its principal artisan. The political situation was difficult and implied the risk that we might be forced, like in 1951, to postpone the GA. That did not happen, and the Prague GA was a success.

It must be stressed here that one of the essential assets of the General Secretary is the quality of the Secretariat. When I became General Secretary, I somehow inherited the person we used to call Miss IAU. Donald Sadler had first benefited from the help of Nell Splinter, the first Miss IAU, then of Dorothy Bell, who followed me to Nice and was a great help to me, before she married Jack Brandt. Thanks to the good offices of 
Luboš, it was not a Miss IAU who succeeded Dorothy, but a Mister IAU, Arnost Jappel, a Czech lawyer. Like both Misses IAU that had preceded him, Arnost accomplished his job in a remarkable way; but being uninitiated in the world of astronomers, it sometimes happened to him to cause funny oddities. One of his responsibilities was the preparation of the IAU Information Bulletin in which he announced Colloquia and Symposia that were in preparation. As such, he announced one day a Symposium in honour of the "late professor Van Biesbroeck". A few days later we received a post card signed by the participants of the Symposium, particularly from Van Biesbroeck himself, who wrote that he was alive and well...

During the following period, 1967-1970, the General Secretary was thus Luboš Perek. The Special Nominating Committee had proposed Otto Heckmann, of whom we had seen the great efficiency at the occasion of the Hamburg GA, to be the next President. One had, of course, to ask for his consent. This was the role of Pol Swings. We were in his office at Liège. In front of me, he calls Heckmann and asks him to accept to become President of the IAU.

"Dear Pol Swings, I do not know if I can accept, are you aware that I was a former member of the national-socialist party?"

"But", replied Pol, "have you ever done anything objectionable?"

"Certainly not! But still, that could be wrongly seen, misunderstood".

Then I said to Pol : "Give me the telephone."

"Professor Heckmann, I heard your conversation with Pol. I wish to tell you that my father and my mother died, deported to the Auschwitz camp. Well, I ask you to accept to become President of the IAU".

The GA took place in Prague under the presidency of Heckmann. It was an excellent GA, during which we were in contact with the beautiful activity of the astronomers in Prague, Ondřejov, and Tatranská Lomnica. I recall this period with pleasure, and I kept amicable relations in Czechoslovakia for a long time.

From 1967 (Prague) to 1970 (Brighton) I still was adviser to the EC, being the former General Secretary. These were for me peaceful, rich, and amicable meetings. I specifically recall the EC meeting in Rome, where we were invited by Livio Gratton: an opportunity for me to revisit the statue of Moses by Michelangelo, one of the works of art that I admire the most. The General Secretary was Luboš, the Assistant General Secretary my old friend Kees de Jager, with whom I always kept very affectionate ties.

I also remember conflicts: Martin Schwarzschild was particularly dynamic, he has often interrupted me: "I obdddject!" ... The exchange was not always very courteous, but I remember from these rare affronts only pleasant memories, that by and large mostly were a token of shared friendships.

Once I had left the EC, I had no less important activities: President for two terms of Commission 5, that often changed name and that mainly dealt with the norms of publishing; President of the Special Nominating Committee; President of the Resolutions Committee. This latter task sometimes led me to oppose EC decisions, especially about the question of the digitisation of photographic-plate archives by the different observatories, in particular those of the Carte du Ciel.

The Comité National Français d'Astronomie (CNFA) had invited the IAU to hold its GA in Grenoble in 1976. An association was formed, l'Association France - IAU 76. I was its President, and the Officers comprised Suzanne Débarbat and André Boischot. It was a lot of work, but the Université de Grenoble helped us a lot, thanks to Michel Soutif, Professor of Physics, and an old friend from the École Normale Supérieure. I had 
been invited by the EC to deliver one of the plenary lectures, on the interstellar medium. The session was presided over by one of the Vice-Presidents, Charles Fehrenbach, then director of the Marseilles Observatory. It was a catastrophe! I had dropped the box of slides before putting them into the projector... I had to deliver the lecture with gestures and words only... Literally a catastrophe! But the public could at least follow my text, which I had been careful to distribute beforehand in two languages to the audience.

And then... I participated at all IAU GAs, until the one in Rio de Janeiro in 2012. In Brazil, I walked with two crutches. It was impossible for me to go to Honolulu, so far away, nor today to Vienna, so much closer... You can imagine how much I regret it.

From all these years I keep wonderful memories and numerous friends. I salute today all my colleagues that are present at this Symposium; from afar I also salute my old friends: Luboš Perek, our centenary, and Kees de Jager - who could not be among you.

I address, especially today, all of you, young astronomers, who will make the astronomy of tomorrow. Thank you for what you are doing! Merci for everything you will do! And, "Bon vent!" - good luck.

\section{Appendix A. Original contribution in French, rendered by voice-to-text software}

C'est très tôt que j'ai entretenu avec l'UAI un rapport véritablement affectif. En 1946, je commençais ma vie de "thésitif" (graduate student). II fallait s'orienter vers les atmosphères stellaires, un domaine qui n'était alors que trop peu couvert en France. Mon mentor (devenu mon ami pendant toute sa vie) Evry Schatzman, m'avait dit clairement que, spécialiste des intérieurs stellaires, il ne saurait pas diriger mes recherches, et qu'il fallait donc apprendre mon métier à l'étranger. C'était, selon lui, à Utrecht qu'il fallait aller. Mais à l'époque, le contrôle des changes était extrêmement dur et l'on ne pouvait pas voyager facilement, car on ne pourrait pas, aux Pays-Bas, être payé en francs; trouver à se loger était aussi une impossibilité. C'est grâce à l'aide de I'Union Astronomique Internationale que ces problèmes ont pu être résolus. A l'époque, le lieutenant-colonel Stratton, qui avait été Secrétaire Général de l'UAI, était Président de la commission qu'il avait fait créer, la commission 38, des "échanges d'astronomes". L'échange eut donc lieu entre Jakob Houtgast, qui désirait travailler en France, et moi; nous avons échangé salaire et appartement. Un appartement que j'ai d'ailleurs partagé avec Kees de Jager, qui travaillait aussi pour sa thèse. Ce fut, sous l'égide de l'UAI, un séjour agréable et fécond, dirigé par le merveilleux Marcel Minnaert, qui reste encore aujourd'hui pour moi l'image tutélaire d'un bienveillant mentor. L'année fut productive: plusieurs articles sur la formation des raies spectrales solaires et stellaires. Cet échange, sous l'égide de la commission 38, se prolongea l'année suivante jusqu'en 1948; de même, alors que Mogens Rudkjöbing passa l'année à l'Institut d'Astrophysique de Paris, je séjournai plusieurs mois à Copenhague, où j'appris de Bengt Strömgren la construction de modèles d'atmosphères stellaires dans le cas dit "non gris" ... Une autre année merveilleuse grâce à l'UAI. Merci, à la commission 38 de I'UAI!

En 1948, I'Assemblée Générale de Zürich fut la première occasion après la guerre, pour les astronomes du monde entier, de se réunir, comme ils l'avaient fait en 1938 à Stockholm. Bien entendu, j'étais trop jeune pour y assister. Mais je me rappelle qu'en 1947 déjà, nous avions eu à Utrecht la visite d'Édith Müller, qui était en train d'organiser cette Assemblée Générale (AG), et qui apporta aux jeunes chercheurs d'Utrecht du chocolat suisse. Splendide Edith!

En 1951, I'AG de I'UAI devait se tenir à Leningrad. Mais l'atmosphère politique était celle de la guerre froide; la majorité du Comité Exécutif (CE; principalement son président Brertil Lindblad et son secrétaire général Bengt Strömgren) décida d'annuler cette AG. Un certain nombre d'astronomes protestèrent alors, au nombre desquels bien sûr Minnaert, Schatzman, de Jager, et moi-même. Nos collègues italiens offrirent aussitôt de tenir l'AG à Rome; mais pour des raisons évidentes d'organisation, il fallut attendre 1952. L'AG de 1952 fut pour moi l'ouverture vers le grand monde de l'astronomie mondiale.

J'avais participé en janvier et février 1952 à l'expédition du Bureau des Longitudes à Khartoum (alors au Soudan Anglo-Egyptien) afin d'y observer l'éclipse de Soleil du 25 février. Notre équipe, avec Marius Laffineur qui la dirigeait, Raymond Michard, et André Cassagnol, obtint de très bons 
résultats que je fus chargé de présenter à la commission 13 (éclipses solaires), que présidait alors Donald Menzel, directeur de l'Observatoire de Harvard. Apparemment, mon exposé lui plut. II m'offrit une superbe cravate, et surtout me proposa une bourse Fulbright pour passer une année au High Altitude Observcatory (HAO) à Boulder (Colorado) avec son directeur Walker Orr Roberts. Ce séjour fut passionnant. Merci, commission 13 de l'UAl!

Après Rome 1952, ce fut Dublin 1955. . . J'y allai, comme plus tard à toutes les AG de I'UAI - sauf hélas les deux dernières, Honolulu et Vienne. L'AG suivante, en 1958, eut lieu en URSS (enfin!), à Moscou. Ce fut pour beaucoup de raisons une réunion mémorable. Schatzman et moi avions été quelque peu choqués par le fait que certaines commissions nouvelles (la commission 40 de radioastronomie, notamment), mais aussi des commissions plus anciennes (Carte du ciel, par exemple), étaient des commissions techniques dont les intérêts se distribuaient entre plusieurs commissions scientifiques.. O Ò̀ allait-t-on parler désormais de la couronne solaire? Commission 40, ou commission 13, voire 12 ou 10 ? II nous sembla qu'une réorganisation des commissions, avec peut-être un système à double entrée, serait nécessaire et nous avions écrit au Comité Exécutif une lettre, que dans mon souvenir il me plaît aujourd'hui de considérer comme incendiaire. Nous avions réagi, nous étions contents de nous-mêmes, - et bien sûr nous n'y avons ensuite plus pensé...

Le temps passe. Au cours de l'année suivante, Schatzman et moi recevons un coup de fil de Donald Sadler, le secrétaire général, qui assumait alors la charge d'un second mandat de trois ans, pour nous inviter à une réunion avec le Président Jan Oort, et Piet Oosterhoff, qui jouait alors le rôle (non statutaire!) d'un secrétaire général adjoint. Ce furent à Leyde quelques jours bien remplis: les meilleurs restaurants de la ville, ses plus beaux musées, ... Mais aussi quelques débats avec nos hôtes. II n'en sortit pas grand-chose et nous sommes repartis tout contents à Paris.

L'été suivant ce fut l'AG de Berkeley. Dès mon arrivée sur le campus, je trouve dans mon "pidgeon hole" [sic] $\dagger$ un mot de Donald Sadler: "J'ai besoin de vous voir dès votre arrivée à Sydney [sic]." Je me précipite dans son bureau. "Le CE a décidé la création d'une nouvelle fonction: celle de secrétaire général adjoint; voulez-vous devenir dans les trois ans qui viennent secrétaire général adjoint de I'UAI?" Grande surprise de ma part. C'était un grand honneur, la reconnaissance en quelque sorte d'un statut d'astronome de réputation internationale, et une conclusion de nos réunions de Leyde. "Je suis très honoré, mais il faut quand même que je réfléchisse". "Certes! Je veux votre réponse avant la prochaine réunion du CE, samedi prochain". Je consultai donc mes mentors André Danjon, le pape de l'astronomie française, Directeur de l'Observatoire de Paris, et membre du CE de I'UAI: "Vous devez accepter - pour la France". Mon mentor, Évry Schatzman: "Bien sûr que tu dois accepter. . cela me permettra de devenir président ...(!!)". Mon vieux maître, Marcel Minnaert: "II faut accepter; c'est une chance pour nos idées progressistes". Une seule voix fut discordante, celle de Jean-François Denisse, le maître de la radioastronomie française: "Tu dois refuser. Si tu acceptes, ta carrière scientifique est fichue...". J'ai suivi mon ambition et j'ai accepté. Je ne l'ai jamais regretté.

Les trois années suivantes, 1961-1964, aux côtés de Donald Sadler, furent des années d'apprentissage. Les relations avec le Président Victor Ambartsumian étaient rares mais excellentes; il nous avait demandé de ne pas l'inonder de courrier inutile. Je fus chargé des publications de I'UAI, de l'organisation des symposiums, et de leurs édition. Avec ma secrétaire, la chère Geneviève Drouin, nous avons fait de fréquents voyages à Birkenhead (près de Liverpool), où se trouvait notre imprimeur, un fort brave homme dont j'ai oublié le nom, mais qui fit un excellent travail pour la publication des Transactions. Je devais aussi souvent me rendre à Hertsmonceux, où l'Observatoire royal de Greenwich avait été délocalisé. Je séjournais alors au château, et je partageais mes petits déjeuners avec l'astronome royal, Sir Richard Woolley; il m'est même arrivé de tenir une batte de cricket. . . mais surtout je travaillais avec Sadler. Donald et moi avions décidé de la publication d'un troisième volume des Transactions, le "Astronomer's Handbook", publié dans nos deux langues, tête-bêche. Ce fut le seul de l'histoire de l'UAl et je le regrette. C'est de cette période que la date aussi l'homogénéisation dans les publications des symboles, des sigles et des abréviations à adopter par tous les éditeurs.

Vint I'AG de Hambourg, en août 1964. J'allais devenir secrétaire général. C'était mon premier contact avec l'Allemagne depuis la guerre; un contact en demi-teinte. J'avais beaucoup souffert en $1944 \ldots$ Le président du comité d'organisation était Otto Heckmann, un homme calme, sage

$\dagger$ Il s'agit d'une boîte aux lettres attribuée à chacun des participants (NDLR). 
et efficace. Ce fut un bon congrès. Le nouveau Président de I'UAl était Pol Swings, directeur de l'institut d'astrophysique de Liège, et que je connaissais déjà depuis de nombreuses années pour avoir participé fréquemment aux excellents colloques annuels de Liège. Travailler avec mon ami Pol fut extrêmement facile, puisque je pouvais aller en voiture à Liège depuis Paris et même de Nice (dont j'étais à l'époque directeur de l'Observatoire), sans aucune difficulté. Le secrétaire général adjoint fut Luboš Perek, un choix particulièrement judicieux, puisqu'il permettrait de résoudre plus facilement les problèmes que posaient l'organisation d'une AG à Prague, prévue pour 1967. Je trouvai vite en cet excellent successeur un fidèle ami... Nous nous donnions souvent rendez-vous en des endroits improbables, à des heures matinales: devant le Taj Mahal à six heures du matin, ou sur le Pont des Arts à Paris, au lever du soleil... Le problème essentiel de ce triennat fut l'organisation de l'AG de Prague. II est clair que Luboš en fut l'artisan principal. La situation politique était difficile et risquait de nous obliger, comme en 1951, à repousser l'AG. C'est ne fut pas le cas, et l'AG de Prague fut un succès.

II faut dire ici qu'un des atouts essentiels du secrétaire général est la qualité de son secrétariat. Devenu secrétaire général, j'avais hérité en quelque sorte de la personne que nous appelions "Miss IAU". Donald Sadler avait bénéficié d'abord de l'aide de Nell Splinter, la première Miss IAU, puis de Dorothy Bell, qui me suivit à Nice et me fut d'un grand secours, avant de se marier avec Jack Brandt. Grâce aux bons offices de Luboš, ce ne fut pas une Miss IAU qui succéda à Dorothy, mais un Mister IAU, un juriste tchèque, Arnost Jappel. Comme les deux Misses IAU qui l'avaient precédé, Arnost accomplit un travail remarquable; mais, nouveau dans le monde des astronomes, il lui est parfois arrivé de commettre d'amusants impairs. L'une de ses responsabilités était la préparation du Bulletin d'information de l'UAI; il y annonçait notamment les colloques et les symposiums en préparation. Ainsi annonça-t-il un jour la tenue d'un symposium en l'honneur de "feu le professeur Van Biesbroek". Quelques jours après, nous avons reçu une carte postale signée de tous les participants du symposium, notamment de Van Biesbroek lui-même, qui écrivit qu'il était bel et bien en vie...

Dans la période suivante, 1967-1970, le secrétaire général fut donc Luboš Perec. Le comité spécial des nominations avait proposé comme Président Otto Heckmann, dont nous avions vu la grande efficacité à l'occasion de l'AG de l'Hambourg. II fallait demander évidemment l'accord de l'intéressé. C'était le rôle de Pol Swings. Nous étions dans son bureau, à Liège. Devant moi, il téléphone à Heckmann et lui demande d'accepter d'être le prochain Président de I'UAI. "Cher Pol Swings, je ne sais pas si je peux accepter; savez-vous que j'ai été jadis membre du parti national-socialiste?". "Mais", répondit Pol, "vous n'avez jamais rien fait de répréhensible?". "Certes non! Mais quand bien même, cela pourrait être mal perçu, mal compris". Alors j'ai dit à Pol: "Passez-moi le téléphone". "Professeur Heckmann, j'ai entendu votre conversation avec Pol. Je veux vous dire que mon père et ma mère sont morts, déportés dans le camp d'Auschwitz. Eh bien, je vous demande d'accepter de devenir Président de I'UAI." L'AG eut lieu à Prague, sous la présidence d'Heckmann. Ce fut une excellente $A G$, au cours de laquelle nous avons pu constater la belle activité des astronomes de Prague, d'Ondřejov, de Tatranska Lomnitza [sic]; j'évoque cette période avec plaisir, et j'ai longtemps gardé des relations très amicales en Tchécoslovaquie.

De 1967 (Prague) à 1970 (Brighton), je fus encore membre à titre consultatif du CE en tant qu'ancien secrétaire général. Ce furent pour moi des réunions paisibles, riches, amicales. Je me rappelle notamment la réunion du CE à Rome, où nous avait invités Livio Gratton: I'occasion pour moi de revoir la statue de Moïse par Michel-Ange, une des œuvres que j'admire le plus. Le secrétaire général était Luboš, le secrétaire général adjoint mon vieil ami Kees de Jager, avec qui j'ai toujours conservé des liens très affectueux... Je me souviens aussi des conflits: Martin Schwarzschild était particulièrement dynamique, il m'a souvent interrompu: "I obdddject!" ... L'échange n'était pas toujours très courtois, mais il ne me reste de ces rares affrontements qu'un bon souvenir, qui fut surtout celui d'amitiés partagées.

Éloigné ensuite du $\mathrm{CE}$, je n'en eus pas moins des activités importantes: président pour deux mandats de la commission 5, qui a changé souvent de nom et qui s'occupait principalement des normes de publication; président du comité spécial des nominations; président du comité des résolutions. Cette dernière tâche m'opposa parfois aux décisions du CE, notamment lorsqu'il fut question de la numérisation des plaques photographiques archivées par les différents observatoires, en particulier celles de la Carte du ciel. 
Le comité national français d'astronomie (CNFA) avait invité I'UAI à se réunir à Grenoble en 1976. Une association s'était constituée, I'association "France-UAI 76". J'en étais le président, et le bureau était constitué de Suzanne Débarbat et d'André Boischot. Ce fut beaucoup de travail, mais l'université de Grenoble nous aida beaucoup, grâce notamment à Michel Soutif, professeur de physique et vieil ami de l'Ecole normale supérieure. J'avais été invité par le CE à faire l'une des conférences plénières, sur le milieu interstellaire. La séance fut présidée par l'un des vice-présidents, Charles Fehrenbach, alors directeur de l'Observatoire de Marseille. Ce fut une catastrophe! Je fis tomber la boîte de diapositives avant de les mettre dans le projecteur. . . Il fallut donner la conférence seulement avec des gestes et des mots... Vraiment une catastrophe! Au moins les auditeurs eurent-ils mon texte sous les yeux, alors que je l'avais fait distribuer à l'avance en deux langues dans l'assistance.

Ensuite...J'ai participé à toutes les AG de I'UAI, jusqu'à celle de Rio en 2012. Au Brésil, je marchais avec deux cannes anglaises. II m'a été impossible d'aller à Honolulu, si lointaine, ni même aujourd'hui de me rendre à Vienne, beaucoup plus proche ... Vous pouvez deviner combien je le regrette.

Je garde de toutes ces années un souvenir merveilleux et de nombreux amis. Je salue aujourd'hui tous mes collègues présents à ce symposium; de loin je salue aussi mes vieux amis: Luboš Perec, notre centenaire, et Kees de Jager, - qui n'ont pu être parmi vous. Et je m'adresse surtout aujourd'hui à vous tous, jeunes astronomes, qui feront l'astronomie de demain. Merci de ce que vous faites! Merci de tout ce que vous ferez! Et "Bon vent!" 